\title{
Pembelajaran Inovasi Kebijakan Inklusif
}

\author{
Dzunuwanus Ghulam Manar \\ Universitas Diponegoro \\ dgmanar@gmail.com
}

\section{ABSTRAK}

Pemerintah dengan kebijakan yang dimiliki tidak lagi mampu menjadi aktor utama dalam pemberdayaan kaum muda. Peran pemerintah yang dominan tanpa diikuti dengan ketersediaan anggaran yang memadai menjadikan kebijakan kepemudaan yang dilakukan oleh pemerintah banyak menemui hambatan. Pada sisi lain, ketergantungan yang sangat tinggi kepada anggaran pemerintah menjadikan kaum muda tidak banyak memiliki prakarsa dan kemandirian. Masalah ini membutuhkan strategi penyelesaian yang berbeda dengan pendekatan-pendekatan kebijakaan kepemudaan yang selama ini telah dilakukan sehingga dibutuhkan terobosan atau inovasi kebijakan kepemudaan. Kompleksitas masalah, dinamika perubahan zaman, serta tuntutan profesionalitas mengharuskan pemerintah melakukan inovasi kebijakan pemberdayaan kaum muda. Kebijakan inklusif dapat dipandang sebagai salah satu strategi inovasi karena kebijakan ini membuka ruang partisipasi dan keterlibatan aktif dari semua pihak di luar pemerintah. Sektor swasta dan organisasi masyarakat sipil menjadi aktor-aktor penting karena ide, prakarsa, dan kemandirian yang mereka miliki dapat memperkaya kebijakan kepemudaan pemerintah. Namun nampak bahwa pemerintah belum memiliki gagasan yang komprehensif mengenai kebijakan kepemudaan yang inklusif. Melalui identifikasi terhadap praktik-praktik terbaik kebijakan pemberdayaan kaum muda yang inklusif dari luar negeri diharapkan dapat mendorong keterbukaan pemerintah untuk berjejaring dan bersinergi dengan stakeholder kebijakan kepemudaan. Langkah ini merupakan bentuk keniscayaan inovasi kebijakan agar pemberdayaan kaum muda dapat berjalan dengan komprehensif, efektif, dan efisien. Kebijakan pemerintah yang terbatas dan otoritatif sehingga menimbulkan ketergantungan dalam pemberdayaan perlu direduksi dan direvisi melalui adopsi dan inovasi kebijakan sejalan dengan semangat partisipasi publik.

KATA KUNCI Inovasi | Kebijakan | Pemberdayaan | Kaum Muda

\section{PENDAHULUAN}

Kebijakan selalu berkaitan dengan tindakan pemerintah, umumnya berupa tindakan melalui program-program pemerintah. Yang umum menjadi rujukan tentang kebijakan adalah hal-hal yang dilakukan oleh pemerintah (Dye 2013). Meski demikian tidak semua yang dilakukan oleh pemerintah dapat juga dinyatakan sebagai kebijakan. Konsep tersebut diyakini sebagai konsep yang cukup komprehensif dalam memahami sebuah kebijakan karena berkaitan dengan tindakan pemerintah.

Dalam memahami sebuah kebijakan, tidak bisa dilakukan hanya sepintas lalu saja. Pada hakikatnya kebijakan adalah hasil dari pertarungan ideide dan gagasan dalam rangka menyelesaikan masalah yang dilakukan oleh pemerintah (Heywood 2013). Perumusan yang kemudian diikuti serangkaian proses lain guna menghasilkan sebuah kebijakan adalah proses yang harus dilakukan oleh pemerintah (Howlett and Ramesh 1995). Semua hasil yang menjadi sebuah kebijakan merupakan kompromi dan kolaborasi atas berbagai alternatif dan gagasan sebagai bentuk upaya tindakan pemerintah guna mencapai tujuan. Gagasan dan alternatif yang dinegosiasikan sudah barang tentu merefleksikan nilai-nilai spesifik yang bermanfaat bagi publik seperti etika demokrasi serta martabat kemanusiaan (Deleon and Martell 2006).

Di antara aspek-aspek yang penting dalam pencapaian tujuan, terdapat instrumen kebijakan 
yang merupakan karakteristik terlaksananya sebuah kebijakan (Bridgman and Davis 2013). Instrumen berkaitan dengan metode dan alat yang digunakan untuk mencapai tujuan. Paling tidak terdapat empat instrumen pokok yang sangat penting bagi tercapainya sebuah kebijakan, yakni hukum, tindakan, advokasi, dan uang. Instrumen hukum berupa hasil legislasi, kebijakan, dan peraturan yang menjadi kerangka acuan tindakan kebijakan. Instrumen tindakan berkaitan dengan hal yang dilakukan pemerintah untuk mencapai tujuan (service delivery). Adapun instrumen advokasi berupa justifikasi atau argumen kebijakan yang harus disampaikan kepada publik secara persuasif dan sebagai bentuk pendidikan kepada publik. Terakhir dan kadang dipandang sebagai instrumen pokok adalah keuangan yang menjadi alat utama mewujudkan instrumen-instrumen lain.

Kebijakan kepemudaan di Indonesia, sebagai salah satu bagian dari tindakan pemerintah, memiliki karakteristik yang unik. Melalui populasi sejumlah 63,36 juta atau setara dengan $25 \%$ dari jumlah populasi Indonesia (BPS 2017), kebijakan kepemudaan masih belum memiliki skema yang jelas untuk mengelola urusan-urusan kaum muda, termasuk di antaranya pemberdayaan yang mencakup peningkatan dan perluasan peluang kerja. Dari total anggaran Kemenpora tahun 2017 sebesar 4,3 triliun, alokasi program yang langsung berkaitan pemuda hanya sekitar 103 miliar (2,39 \%) melalui Strategi Peningkatan Pembangunan Karakter, Tumbuhnya Jiwa Patriotisme, Budaya Prestasi dan Profesionalitas serta Partisipasi Pemuda (Rencana Kerja Kementerian/Lembaga 2017 Kemenpora). Dari nomenklatur program tersebut belum nampak kebijakan pada bidang kepemudaan berorientasi kepada lapangan kerja. Oleh karena itu, hanya mendasarkan kepada kebijakan saja belumlah memadai.

Beberapa penelitian tentang pemuda dan pemberdayaannya masih memunculkan beragam masalah, seperti ketergantungan kepada pemerintah, misalnya pemerintah desa (Chuncoro 2011), kekurangan modal, akses pemasaran, kebijakan dan bantuan pendanaan pemerintah (Balitbang Jawa Timur dan UNESA 2014), perlu kerjasama dengan berbagai stakeholder (ILO 2014) keterbatasan akses khususnya bagi pemuda penyandang disabilitas (Poerwanti 2017) serta kurangnya kerangka kebijakan yang integral (UNESCO 2013). Hal tersebut tentu perlu mendapatkan respons dan revisi, alih-alih dari kacamata inklusif, terlihat masih sangat dominan peran pemerintah dan negara dalam pengelolaan kebijakan kepemudaan.

Dominasi peran pemerintah dan negara belum diikuti dengan pelibatan stakeholder kepemudaan, khususnya dari sektor privat (kalangan bisnis dan dunia usaha) maupun masyarakat sipil. Hasilnya adalah kekurangan dalam ranah implementasi kebijakan karena sumber daya pemerintah di bidang kepemudaan masih terbatas. Oleh karena itu, ketika kebijakan tidak lagi bisa memberikan kerangka acuan program yang relevan, maka dibutuhkan prakarsa dan pemikiran-pemikiran baru untuk bisa menyelesaikan masalah-masalah yang timbul. Pemerintah tentu memiliki keterbatasan dalam menyikapi masalah-masalah kepemudaan yang kompleks dan beragam. Kebijakan yang dibuat belum tentu kompatibel dengan situasi yang ada. Padahal kebijakan hakikatnya memiliki karakteristik penyelesaian masalah melalui pendekatan multidisiplin dengan berdasar kepada nilai-nilai tertentu (Deleon and Martell 2006).

Kaitannya dengan pemberdayaan pemuda, tidak ada dokumen kebijakan spesifik yang mewajibkan pemerintah pusat maupun daerah memberikan perhatian lebih serius. Padahal tantangan seperti munculnya bonus demografi, tuntutan produktivitas, persaingan antarnegara, maupun skema pemberdayaan pemuda yang lebih inovatif dan modern perlu dilakukan oleh pemerintah. Inovasi, misalnya, adalah hal yang tidak bisa dihindari di era ini. Banyak definisi tentang inovasi namun secara sederhana dapat dimaknai perbaikan kinerja pemerintah sebagai respon atas tuntutan warga negara (Considine, Lewis and Alexander 2009), cara berpikir dan bertindak yang baru (Martinez 2012), serta upaya perbaikan kinerja pemerintah (Hunmin 2006). Inti dari inovasi sendiri adalah perubahan, perbaikan, penggunaan sesuatu yang berbeda, baik kepada proses atau cara maupun hasilnya, dari proses inisiatif internal maupun mengadopsi dari eksternal (Kasali 2015). 
Berkaitan dengan konsep-konsep tersebut, pemerintah perlu meninjau kembali kebijakan kepemudaan dan menjadikan inovasi sebagai strategi perbaikan kebijakan. Oleh karena itu, perlu ada rumusan strategi baru untuk menyelesaikan masalah-masalah pemberdayaan pemuda melalui inovasi, misalnya dengan strategi inklusif yakni dengan pelibatan stakeholder di luar pemerintah (outreaching), khususnya sektor swasta dan masyarakat sipil. Dalam konteks ini terdapat pengalaman-pengalaman terbaik (best practices) dari beberapa negara yang bisa menjadi acuan pelaksanaan di Indonesia. Setidaknya dapat menjadi inspirasi untuk diadopsi sebagai sebuah alternatif kebijakan kepemudaan yang lebih baik.

\section{METODE PENELITIAN}

Tulisan ini disusun dengan library/desk study yang banyak mengandalkan pada referensireferensi tertulis sebagai data utama. Buku dan jurnal yang relevan dengan strategi pemberdayaan pemuda secara inklusif menjadi acuan utama dalam penulisan ini. Data yang diperoleh kemudian disusun menjadi cluster yang relevan dengan objek pembahasan untuk kemudian dianalisis. Temuan praktik-praktik dan implikasi kebijakan yang telah ada ditelaah untuk ditemukan penyebab utamanya. Kemudian, dengan melakukan identifikasi terhadap praktik-praktik terbaik (best practices) dari beberapa wilayah, data dijadikan referensi utama sebagai acuan pengembangan pemberdayaan pemuda yang selama ini telah dilaksanakan. Dengan demikian, tulisan ini diharapkan memberikan kajian kritis sekaligus menyodorkan sebuah alternatif adopsi kebijakan kepemudaan yang lebih komprehensif.

\section{KERANGKA TEORI}

Selama dasawarsa terakhir sejak tahun 2000an, istilah inovasi menjadi sesuatu yang sangat populer. Hampir semua orang terpukau dengan praktik-praktik inovasi pada semua hal karena merupakan terobosan, hal yang baru yang belum pernah ada sebelumnya. Meski demikian, fokus inovasi masih saja pada hasil (output) dari inovasi itu sendiri (Grindle 2010). Padahal perlu diperhatikan bahwa proses inovasi tidak kalah pentingnya. Untuk sampai pada hasil inovasi (output), sebagaimana halnya kebijakan, dibutuhkan usaha-usaha untuk menemukan ide dan gagasan, memilih untuk diujikan atau mencobanya untuk dituangkan dalam bentuk praktis serta yang terakhir memublikasikan kepada publik (Dudley and Richardson 2000). Hal ini berarti inovasi juga melalui serangkaian proses yang membutuhkan sumber daya cukup besar, terutama usaha untuk menemukannya dan waktu untuk berproses.

Pada dasarnya inovasi bukan hal yang baru dalam konteks pemerintahan (Kamarck 2003). Thatcherism dan Reaganomics yang kita kenal pada tahun 1970-1980an merupakan momentum dimulainya inovasi dalam bidang pemerintahan yakni saat Margaret Thatcher terpilih sebagai Perdana Menteri Inggris dan diikuti oleh Ronald Reagan sebagai Presiden Amerika Serikat tahun 1980. Kampanye kedua kandidat tersebut menawarkan perbaikan birokrasi dan pemerintahan, layanan pemerintahan yang sesuai dengan harapan warga negara serta penyediaan layanan publik yang menjadikan birokrasi bekerja demi kenyamanan warga negara. Tentu saja program ini menuai banyak dukungan warga negara yang membuat kedua kandidat tersebut terpilih. Sejak saat itu pemerintahan Thatcher dan Reagan memberikan banyak perubahan tata kelola pemerintahan yang lebih baik dibandingkan waktu sebelumnya.

Sejarah manusia dan perkembangan peradaban pada dasarnya adalah proses inovasi, yakni perbaikan kinerja serta respons atas tuntutan warga negara (Considine, Lewis, and Alexander 2009). Secara sederhana inovasi adalah evolusi ide manusia yang berlangsung sepanjang waktu, baik karena dorongan penyelesaian masalah maupun melakukan penyelesaian masalah dengan menggunakan caracara yang berbeda. Hal ini merupakan konsekuensi logis dengan adanya rasionalitas pada diri manusia. Manusia tentu tidak akan pernah merasa puas dan ketidakpuasan ini tersalurkan melalui penemuan atau terobosan baru yang dikenal dengan nama inovasi. Penemuan tentang cara-cara baru dalam mengatasi tantangan hidup maupun pranata, infrastruktu,r maupun alat yang kemudian dikenal dengan teknologi, pada hakukatnya menjelaskan proses dari inovasi. 
Pada konteks ini paling tidak terdapat tiga pernyataan mendasar tentang inovasi, yakni berkaitan dengan produk dan proses, radikal dan inkremental serta normatif.

Produk dan proses berkaitan dengan alasan dari kegiatan yang dinamakan inovasi. Misalnya, apakah berarti menghasilkan atau membuat sebuah desain jebakan tikus yang lebih baik ataukah kegiatan pelatihan bagi orang yang menggunakan jebakan tikus? Pada tataran orang termasuk di dalamnya kegiatan maka perubahan atau inovasi berhubungan dengan sebuah proses produksi berupa hasil ataupun cara yang digunakan untuk memproduksi. Ilustrasi mengenai sebuah produk jebakan tikus yang lebih baik ataupun sebuah pelatihan untuk menggunakan jebakan tikus merupakan sebuah generalisasi sederhana tentang produk atau hasil dan proses. Keduanya dapat berjalan seiring dan dapat pula berdiri sendiri. Oleh karena itu, kajian tentang inovasi, termasuk di dalamnya inovasi pemerintahan dapat berkaitan dengan hasil maupun proses.

Kedua berkaitan dengan radikal dan inkremental yakni dampak dari inovasi. Identifikasi apakah inovasi adalah sebuah terobosan atau lompatan dari praktik-praktik yang telah biasa dilakukan saat ini dengan berbagai dampak sosial, ekonomi, dan politik yang merupakan pertanyaan mendasar. Pada konteks ini jebakan tikus tidak semata-mata dilihat sebagai sebuah proses penemuan baru, namun dapat pula diidentifikasi sebagai cara untuk mengurangi spesies tikus dan melindungi ekosistem. Hal serupa yang sering diilustrasikan adalah perubahan dari kotak es ke lemari pendingin. Keduanya memiliki perubahan yang bersifat total, menyeluruh dan dalam kurun waktu yang singkat. Namun dapat juga merupakan sebuah proses perkembangan dan perbaikan dari temuan-temuan yang telah ada. Dalam kasus atau masalah yang membutuhkan respon cepat, maka pilihan radikal bisa menjadi sebuah solusi untuk memperbaiki maupun menyelesaikan masalah.

Ketiga berkaitan dengan normatif, yakni apakah inovasi merupakan kebaikan atau keburukan serta sebuah perubahan yang disengaja? Penemuan baru tentang jebakan tikus, obat-obat dan pelayanan kesehatan anak mungkin kurang populer dan dramatik daripada perjalanan ke ruang angkasa atau teknologi DNA (Deoxyribonucleic Acid). Namun penting dicatat sebagai budaya inovasi yang memberikan perbaikan signifikan bagi masyarakat, mengingat pada dasarnya kehidupan masyarakat dipenuhi dengan proses-proses perubahan.

Oleh karena itu, inovasi dapat diidentifikasikan dengan sebuah proses perubahan untuk menemukan cara-cara berpikir dan bertindak baru, khususnya dalam pemerintahan berkaitan kebijakan dan layanan (Martinez 2012), tindakan-tindakan dan ide-ide untuk memperbaiki pemerintah (Hunmin 2006), penggunaan teknologi untuk inisiasi, impor, dan modifikasi (Parmentola and Ferratti 2015) ataupun perubahan atas layanan dan kebijakan pemerintah (Pramusinto 2006). Sudah barang tentu tidak ada sebuah definisi yang cocok, namun identifikasi tentang inovasi selalu berkaitan dengan hal-hal yang baru, belum pernah ada sebelumnya dan sudah tentu membawa perubahan dan perbaikan.

Hal yang menarik tentang inovasi adalah bahwa pada dasarnya inovasi datang karena sebuah masalah atau tantangan baik yang berasal dari dalam maupun dari luar sebuah organisasi (Kasali 2015). Perubahan sebagai ruh dari inovasi bisa datang dari faktor internal, yakni upaya untuk maju dan membawa peningkatan ataupun karena dorongan dari lingkungan eksternal seperti karena persaingan dengan organisasi atau daerah lain atau dapat juga karena tuntutan global dengan adanya seperangkat standar yang berlaku universal.

E-Government atau penggunaan teknologi informasi berbasis internet merupakan salah satu bentuk inovasi di bidang pemerintahan. Urusan-urusan pemerintahan yang lamban dapat diselesaikan secara ringkas dan tepat. Selain berkaitan dengan cara baru pemerintah melayani rakyat, inovasi ini juga berkaitan dengan perbaikan sumber daya pemerintah menjadi lebih cepat, efektif, efisien, transparan, dan akuntabel (Indrajit 2006). Hal-hal seperti ini tidak ditemui pada praktik-praktik pemerintahan era sebelumnya sehingga inovasi menjadi strategi dan bukti layanan pemerintahan yang lebih baru dan lebih baik. 
Pada sisi yang lain, dunia maupun tata kelola pemerintahan mengenal pendekatan baru yang dikenal dengan inklusif. Pendekatan ini diperkenalkan oleh Le Noir pada 1974 saat menjabat sebagai Menteri Sosial Perancis. Inklusif adalah makna politis dari sebuah pendekatan kesejahteraan (World Bank 2013). Pendekatan ini merupakan jawaban atas pertumbuhan ekonomi yang menafikan keadaan dan kesejahteraan (Warsilah 2015). Selama ini pendekatan pembangunan dan kebijakan lebih banyak bersifat eksklusif yakni lebih mementingkan prinsip pragmatisme jangka pendek, menggunakan kaidahkaidah yang dangkal serta individualis. Sebaliknya, kebijakan atau pendekatan inklusif mengikutsertakan publik dalam setiap aspek pembangunan dengan tujuan untuk menyelaraskan hak dan kewajiban individu, menciptakan keadilan, kesetaraan, dan kesempatan yang sama meski berasal dari latar belakang yang berbeda (Negara 2013).

Pendekatan inklusif mendorong terciptanya pola pembangunan yang terbuka, ramah, meniadakan hambatan hubungan setiap warga negara karena saling menghargai dan merangkul perbedaan. Modal sosial sebagai landasan inklusivitas harus didorong penciptaannya tidak hanya oleh negara namun juga oleh individu dan masyarakat. Di sinilah diperlukan relasi dan dialektika antara individu dengan masyarakat sebagai kunci keberhasilan komunitas dan organisasi yang inklusif (Victoria State of Government 2016). Strategi inklusif berupaya membangun dan membuka partisipasi dari banyak pihak dengan memberikan peran, kepercayaan dan ruang kolaborasi. Hal ini terjadi karena adanya pemahaman bahwa tidak boleh ada satu pihak pun yang tidak dilibatkan dalam sebuah strategi inklusif. Hal ini berbeda dengan tradisi kebijakan dan pembangunan yang selama ini dilakukan di Indonesia karena masih bersifat eksklusif dengan adanya dominasi peran pemerintah dan negara. Dengan demikian, dapat dikategorisasikan bahwa inklusif merupakan bagian dari inovasi pendekatan pembangunan karena berusaha menggantikan atau menggeser pendekatan yang lama dan menciptakan ruang pendekatan baru yang lebih humanis. Hal ini muncul karena adanya kekurangan terhadap pembangunan dan hasil-hasilnya selama ini.
Maka dari itu perlu dicari dan diidentifikasi pendekatan yang lebih baik.

Salah satu inspirasi pendekatan dalam kebijakan dan masalah sosial berasal dari inovasi yang telah dilakukan pada belahan bumi yang lain. Salah satunya adalah strategi di dalam pemberdayaan pemuda, banyak di antaranya berasal dari belahan bumi utara (metropole). Ada kecenderungan untuk tidak mendikotomikan utara-selatan dalam konteks teori-teori kepemudaan (Azca, Sutopo, and Arrobi 2014). Namun menjadikan referensi untuk didomestikkan atau diadopsi tentu menjadi sebuah pendekatan unik, terlebih berkait dengan strategi kebijakan.

Strategi adopsi inilah yang merupakan pengejawantahan inovasi dengan melihat, mengamati, membandingkan, dan menganalisis praktik-praktik kebijakan kepemudaan yang berlaku di negara-negara maju. Strategi adopsi bukan semata-mata memindahkan model ke Indonesia namun menjadikan inovasi sebagai referensi dan sumber inspirasi kebijakan agar tercipta kebijakan baru yang lebih komprehensif dan lebih baik. Dengan demikian, adopsi dapat dijadikan sebagai pengkayaan strategi dan inspirasi pengembangan pemerdayaan pemuda sesuai dengan situasi dan sumber daya yang dimiliki.

\section{TEMUAN DAN ANALISIS}

Pemerintah tidak lagi menjadi satu-satunya aktor penting dalam pemberdayaan pemuda. Pada kenyataannya negara tidak lagi mampu dan memiliki energi dengan semakin banyaknya tuntutan serta penanganan aspek-aspek kehidupan masyarakat yang semakin kompleks. Berkaitan dengan masalah kepemudaan saja, pemerintah hanya memiliki kerangka kebijakan berupa undang-undang, yakni Undangundang No. 40 tahun 2009 tentang Kepemudaan. Di dalamnya yang berkaitan dengan kesempatan kerja kaum muda hanya diatur dalam pasal 8 tentang peningkatan dan perluasan kerja kaum muda. Sudah barang tentu hal ini menjadi keterbatasan dalam pengelolaan kebijakan kepemudaan mengingat hanya mendasarkan undang-undang saja terlalu jauh, bahkan mungkin hanya menjadikan kebijakan lahir semata karena asumsi (UNESCO 2013). 
Pada tataran praktisnya, jumlah kaum muda Indonesia sekitar 63,36 juta yang setara dengan 25 $\%$ dari total populasi hanya mendapatkan porsi dukungan anggaran negara sekitar 103 miliar atau 2,39\% dari anggaran kementerian pemuda berkaitan dengan upaya-upaya pemberdayaan termasuk peningkatan dan perluasan kerja. Sudah barang tentu banyaknya sektor yang harus dipenuhi berdampak pada kecilnya alokasi anggaran, termasuk anggaran untuk kesempatan kerja bagi pemuda yang harus bersaing dengan sumber daya manusia dari negara-negara tetangga. Untungnya, 51,47 \% dari jumlah pemuda Indonesia telah bekerja dan sisanya bersekolah atau persiapan kerja sehingga keterbatasan upaya pemerintah dalam hal ini dapat diantisipasi secara proaktif oleh kaum muda.

Satu problem mendasar adalah berkaitan dengan anggaran, mengingat dalam kebijakan pemerintah lebih menonjol mata anggaran fasilitasi, yang berupa penyediaan sarana, prasarana, dan juga pembiayaan. Hal ini tercermin dalam undang-undang bahwa strategi fasilitasi dilakukan secara sinergis antara pemerintah dan pemerintah daerah. Namun begitu, detail dan porsi pembagian dalam sinergi ini mengundang pertanyaan karena tidak terjabarkan secara konkret. Hal ini berakibat pada program-program pemberdayaan kaum muda tidak mengalami perkembangan yang pesat karena ketergantungan kepada pemerintah maupun pemerintah daerah dalam hal fasilitasi masih sangat tinggi. Sebagai ilustrasi, pemerintah daerah memiliki banyak keterbatasan berkaitan dengan informasi maupun regulasi seperti perda tentang kepemudaan yang belum ada maupun acuan aturan di bawah undang-undang di bidang kepemudaan yang harus ditindaklanjuti.

Kegagalan atau keterbatasan kebijakan kemudian muncul dan memberikan pengaruh kepada pelaksanaan program atau strategi yang dilakukan oleh pemerintah. Beberapa bukti yang terjadi di lapangan memperkuat hal itu, seperti ketergantungan yang sangat tinggi kepada pemerintah soal anggaran, keterbatasan anggaran pemerintah daerah melakukan fasilitasi karena wilayahnya yang luas maupun belum sinerginya antarkebijakan pemerintah berkaitan dengan pemuda.
Pemerintah Desa Botomulyo, Kecamatan Cepiring, Kabupaten Kendal melaksanakan program pemberdayaan bagi kaum muda melalui Pelatihan Kecakapan Hidup (life skills) berupa ternak kelinci (Chuncoro 2011). Sebanyak 15 orang dari 236 pemuda yang tidak mempunyai pekerjaan diberikan pelatihan ini atas inisiatif dari perangkat desa. Selain bertujuan pragmatis agar para pemuda ini memiliki keterampilan, pekerjaan, dan penghasilan, ada tujuan strategis menjadi Desa Botomulyo sebagai desa penghasil kelinci. Kegiatan yang dimulai sejak Desember 2010 ini dilaksanakan selama tiga bulan. Semua peserta pelatihan memiliki keterampilan pengembangbiakan kelinci, mulai dari memilih bibit unggul, merawat, memberikan pakan dengan nutrisi yang cukup serta perawatan kandang. Hasilnya para peserta dapat melakukan kegiatan pengembangbiakan sendiri dan memberikan pendapatan kepada mereka.

Pada program ini, inisiatif atau prakarsa masih berasal dari pemerintah dalam hal ini pemerintah desa dan dalam pelaksanaannya masih terdapat kendala yakni minimnya peserta yang bisa mengikuti kegiatan (sekitar $7 \%$ dari jumlah populasi pemuda yang menganggur). Tanpa adanya campur tangan, bimbingan, dan bantuan koordinasi dari pemerintah daerah maka program ini sulit untuk berkembang. Pada titik tertentu akan terjadi over supply komoditas kelinci karena tidak adanya pembukaan pasar sebagai respon tidak lanjut intensifikasi program Pelatihan Kecakapan Hidup. Padahal pada konteks ini, pemerintah daerah dapat berperan sebagai fasilitator, baik teknik budidaya maupun penyedia pasar. Di sini, terlihat bahwa inisiatif pemerintah daerah belum nampak.

Karang Taruna sebagai wadah aktualisasi bagi pemuda juga tidak ketinggalan dalam melakukan pemberdayaan kepada kaum muda di Provinsi Jawa Timur. Dari laporan pemberdayaan Karang Taruna yang disusun oleh Balitbang Provinsi Jawa Timur bekerjasama dengan Fakultas Ekonomi Universitas Negeri Surabaya tahun 2014 menegaskan bahwa program pemberdayaan bagi Karang Taruna yang dilaksanakan pada beberapa kabupaten terpilih, seperti Tulungagung, Malang, Lamongan dan Situbondo dilakukan melalui skema Usaha Ekonomi Produktif 
(UEP). Hal ini sejalan dengan kebijakan pemerintah yang tertuang pada Peraturan Menteri Sosial RI No. 77/HUK/2010 tentang Pedoman Dasar Karang Taruna. Beberapa hal penting dari Permensos tersebut adalah adanya perbedaan jenjang usia Karang Taruna yakni 13 - 45 tahun, sementara pada Undang-undang Kepemudaan ditentukan 16-30 tahun, penyelenggaraan kegiatan secara otonom, sosial, terbuka dan lokal dengan tanggung jawab terbagi antara pemerintah dan pemerintah daerah, dan anggaran kegiatan diperoleh dari iuran, usaha serta subsidi pemerintah.

Dari penelitian, analisis serta evaluasi yang telah dilakukan ditemukan hambatan-hambatan seperti kurang solid atau militannya anggota Karang Taruna, kekurangan modal, kurangnya kepercayaan dari pemerintah desa, manajemen tidak bagus, akses pasar yang terbatas serta kebijakan dan bantuan (keuangan) pemerintah yang terbatas.

Kasus ini mirip dengan pemberdayaan di Kendal yang masih bertumpu kepada inisiatif dan prakarsa pemerintah, khususnya pemerintah daerah dan desa. Dengan skema pemberdayaan yang seperti ini bisa dipahami mengapa masih saja muncul hambatan-hambatan dalam pelaksanaan pemberdayaan. Laporan ILO sebagai refleksi atas Penanganan Lapangan Kerja bagi Kaum Muda di Indonesia tahun 2014 menegaskan bahwa pemerintah tidak bisa bekerja sendiri dalam melaksanakan kegiatan pemberdayaan. Dibutuhkan kerjasama dengan pihak lain atau stakeholder agar program pemberdayaan menjadi lebih efektif.

Ilustrasi serta bukti di atas menunjukkan bahwa kebijakan yang dimiliki oleh pemerintah masih bersifat eksklusif karena otoritas pelaksanaan kebijakan masih bertumpu kepada aparat pemerintah. Belum muncul adanya inklusivitas kebijakan pada pemberdayaan kaum muda berupa strategi baru, misalnya dengan pelibatan sektor non-pemerintah maupun penemuan cara-cara baru dalam pemberdayaan kepemudaan. Hal senada juga dirasakan oleh kaum muda disabel yakni pemahaman yang terbatas serta persepsi yang negatif mengakibatkan kebijakan pemberdayaan yang dilakukan belum bersifat inklusif dan terkesan hanya sebagai bagian dari amal (charity) saja (Poerwanti 2017).
Oleh karena itu, pada hakikatnya dibutuhkan adanya sinergitas kebijakan, khususnya internal pemerintah serta peluang untuk berpartisipasi dari pihak nonpemerintah, seperti swasta maupun masyarakat sipil. Selain hal ini merupakan sebuah kebutuhan pada era keterbukaan dan demokratisasi saat ini, pendekatan ini juga mencerminkan adanya sense of inclusive pada kebijakan dan kinerja pemerintah. Praktik-praktik inklusif yang telah dijalankan di negara-negara maju pada dasarnya justru memberikan ruang sinergi dan kolaborasi antara pemerintah, swasta, pasar, masyarakat sipil, dan juga mendorong munculnya modal sosial dan investasi (Negara 2013).

Ketidakmampuan pemerintah mewujudkan pendekatan inklusif pada dasarnya muncul karena pola pendekatan patron-client yang memandang pemuda hanya sebagai objek dan negara sebagai pemilik otoritas. Selain itu, kurangnya referensi dan inspirasi inklusivitas menjadikan kebijakan dan program yang dijalankan hanya sebatas kebiasaan berbasis anggaran tahunan (business as usual). Pendekatan ini tentu bertentangan dengan pendekatan inklusif karena hanya aktor pemerintah yang dominan sehingga pemerintah perlu didorong dengan referensi dan inspirasi pelaksanaan kebijakan inklusif yang telah ada di banyak tempat. Paling tidak hal sederhana yang dapat dilakukan oleh pemerintah adalah mencontoh atau mengadopsi sesuai dengan sumber daya dan instrumen kebijakan yang ada.

Beberapa contoh pendekatan inklusif berikut ini menunjukkan bukti bahwa hal ini dapat dilakukan, baik oleh pemerintah maupun lembaga non-pemerintah melalui skema sinergi yang dirumuskan sebagai sebuah inovasi kebijakan. Contoh-contoh berikut berfokus kepada kebijakan dan strategi networking yang dilakukan oleh dan dengan organisasi/lembaga non-pemerintah.

Matthew Curtis adalah warga Manchester, UK, seorang difabel yang disebabkan oleh kecelakaan dan harus menjalani rehabilitasi dalam waktu yang cukup lama. Di tengah kegalauannya soal eksistensi dan pekerjaan ia bergabung dengan Disabled Go yang di kemudian hari memberinya penempatan kerja sekaligus pekerjaan permanen pada perusahaan Mark and Spencer. Hal yang membanggakan bagi 
Matthew selain soal pekerjaan adalah keterbukaan tempat kerja dan rekan-rekan kerjanya yang memberinya kesempatan untuk maju sesuai dengan kemampuan yang dimilikinya (Equity and Human Rights Commission, Manchester 2010).

Cerita sukses ini dimulai dengan adanya kebijakan pemerintah berupa Equity and Human Rights untuk terlibat dengan menciptakan tempat kerja yang inklusif. Hal yang pertama dan utama adalah perumusan dan pembuatan kebijakan tentang kesetaraan dan hak asasi, yang mana setiap orang diperlakukan secara hormat dan beradab. Selain itu, semua pihak mendapatkan penanaman nilai-nilai inklusif sehingga semua orang didorong untuk berkembang dan membuat kemajuan. Hambatan-hambatan yang muncul diidentifikasi dan sesegera mungkin diselesaikan. Kunci sukses dari strategi ini adalah peran Senior Staff yang memberikan dukungan penuh dan mempromosikan para pekerja.

Paling tidak, saat program ini berjalan terdapat manfaat-manfaat yang diperoleh dari para pihak, di antaranya adalah munculnya individu-individu yang berbakat, komitmen produktivitas yang meningkat serta meningkatkan kepercayaan pelanggan karena adanya kultur perubahan yang terjadi.

Pada sisi lain, hal yang relatif sama terjadi pula di Kanada (Canadian Human Rights Commission 2006). Di bawah Canadian Human Rights Act dan Employment Equity Act pemerintah dan swasta sama-sama memiliki komitmen untuk menjalankan prinsip duty to accommodate. Prinsip ini mendasarkan kepada tindakan-tindakan yang diambil harus berusaha menghilangkan kerugian-kerugian (individu). Prinsip ini berangkat dari asumsi bahwa semua individu harus memiliki kesempatan yang sama dengan individu lain dan mereka terpenuhi kebutuhannya. Guna menjalankan kebijakan ini pemerintah menyediakan instrumen kebijakan yang komprehensif, termasuk pedoman kebijakan pada level praktis yang harus dijalankan pada lembaga atau perusahaan. Skema kebijakan ini mempermudah semua pihak untuk melakukan implementasi atas prinsip inklusif yakni mengakomodasikan semua kebutuhan individu tanpa terkecuali berbasis prinsip-prinsip kesetaraan dan hak asasi.
Cerita sukses yang lain berasal dari ILO (International Labour Organization) tentang inisiatif 10 perusahaan di 8 negara, yakni Brasil, Chili, Tiongkok, India, Norwegia, Serbia, Singapura, dan Amerika Serikat tentang inklusi penyandang disabilitas muda (ILO 2015). Beberapa perusahaan, baik nasional maupun multinasional, memiliki inisiatif dan strategi untuk bermitra dengan penyandang disabilitas muda melalui serangkaian program. Program yang dilakukan antara lain dengan memulai kebijakan inklusi sebagaimana dilakukan oleh ACCOR Hotel Tiongkok dan DELTA Holding di Serbia. ACCOR Hotel melalui jaringannya di Shanghai, yakni Novotel Atlantis Hotel memberikan kesempatan pemagangan dan penempatan kerja bagi penyandang disabilitas muda. Strategi yang dilakukan adalah dengan peers education atau sistem sahabat, yakni bermitra dengan pegawai yang sudah berpengalaman mulai aktivitas personal sampai dengan pekerjaan sesuai bidang masing-masing. Dalam proyek ini pihak hotel bekerjasama dengan Asosiasi Penyandang Disabilitas Shanghai Pudong. Hasilnya memberikan kesempatan kerja kepada 200 penyandang disabilitas muda serta mengedukasi pegawai dan pengunjung tentang kebijakan inklusif bagi semua pihak. Adapun DELTA Holding di Serbia mendirikan Yayasan Delta pada tahun 2007 yang melakukan inisiatif dengan berfokus pada rehabilitasi kerja, jaminan sosial, pendidikan, budaya, dan kesehatan dengan tujuan utama melakukan inklusi sosial dan mempekerjakan penyandang disabilitas di perusahaan. Hal ini dilakukan dengan mendirikan Trade High School dan Pusat Inklusi, Inovasi dan Integrasi di Belgrade. Kegiatan Pendidikan yang dilakukan sampai dengan empat tahun ini berhasil menciptakan akses pekerjaan bagi penyandang disabilitas muda.

Selain melalui kebijakan inklusi perusahaan, kebijakan yang dilakukan adalah rekrutmen, pendidikan dan pelatihan, serta penempatan kerja serta tindak lanjut berupa bimbingan dan fasilitasi penyandang disabilitas muda. Hal ini dilakukan oleh Marriot Group di Amerika Serikat melalui program Bridges yang berhasil menempatkan 13.000 penyandang disabilitas muda pada 3.800 perusahaan. Mphasis, sebuah perusahaan IT di India, dengan penempatan 
dan pelayanan disabilitas melalui pendirian Kantor Pelayanan Disabilitas, serta TELENOR yaitu perusahaan operator seluler di Norwegia dengan program dukungan kerja plus di kelas, praktik kerja nyata serta tindak lanjut sejak 2006. Perusahaan-perusahaan tersebut selain berhasil melakukan program inklusi bagi penyandang disabilitas muda, mereka mendapatkan kredit baik dari konsumen dan publik sebagai perusahaan yang melakukan praktik bisnis penuh tanggung jawab.

Tidak ketinggalan di Yordania Injaz, sebuah organisasi nonpemerintah/lembaga swadaya masyarakat melakukan program pemberdayaan bagi kaum muda sejak 1999 dengan berfokus kepada financial literacy, work readiness, dan entrepreneur training. Injaz bersinergi dengan pemerintah, swasta dan organisasi masyarakat sipil melakukan pemberdayaan kaum muda dengan mengidentifikasi gap pekerjaan dan ketersediaan tenaga kerja. Fokus utama pada aspek sosial, keuangan dan keterampilan kewirausahaan. Hasilnya pada tahun 2015 telah mencapai 1,2 juta kaum muda yang dapat bekerja pada 27.309 tempat kerja dan wirausaha. Pada konteks ini sangat jelas Injaz mampu menaikkan angka pertumbuhan kerja di Yordania.

Mencermati pendekatan-pendekatan tersebut di atas dapat ditemukan adanya cara-cara baru dengan ide baru, strategi networking, serta bottom up empowerment. Paling tidak hal-hal baru tersebut berkaitan dengan hal-hal sebagai berikut:

\begin{tabular}{|l|l|}
\hline 1 & $\begin{array}{l}\text { Kebijakan, baik pemerintah, swasta, maupun } \\
\text { masyarakat sipil yang dibuat secara kreatif } \\
\text { dan inovatif sehingga menjadi kebijakan baru, } \\
\text { yakni kebijakan inklusif. Hal ini terlihat dari } \\
\text { pelibatan kelompok-kelompok di luar pemer- } \\
\text { intah melalui skema dengan kelompok difabel } \\
\text { (Disabel Go), perusahaan (Mark and Spen- } \\
\text { cer), maupun lembaga swadaya masyarakat } \\
\text { (Yayasan Delta, Pusat Inklusi, Inovasi, dan } \\
\text { Integrasi) yang menciptakan skema kegiatan } \\
\text { dan kerja sama baru. }\end{array}$ \\
\hline 2 & $\begin{array}{l}\text { Skema pelibatan aktor non-pemerintah, } \\
\text { seperti swasta dan kelompok masyarakat sipil } \\
\text { yang kreatif, strategis dan memiliki kepen- } \\
\text { tingan berkesinambungan. Hal ini tercermin }\end{array}$ \\
\hline
\end{tabular}

tidak hanya dari pelatihan dan penempatan kerja semata namun juga tindak lanjut keberlanjutannya. Program tidak dilakukan hanya 1-2 tahun saja namun bisa berlanjut sampai dengan berpuluh tahun sebagaimana dilakukan Yayasan Delta sejak 2007 dan TELENOR Norwegia sejak 2006.

3 Strategi yang beragam, baik melalui pendidikan dan pelatihan formal maupun informal, seperti dengan pelibatan sebaya sebagaimana dilakukan ACCOR Hotel Tiongkok, DELTA Holding Serbia, dan Disabled Go di Manchester, UK.

4 Inisiatif datang dari banyak pihak, tidak hanya dari satu pihak atau pemerintah saja.

Inti dari praktik-praktik terbaik yang disajikan adalah pemerintah tidak lagi sebagai aktor utama yang memiliki beban banyak atau tumpuan dalam pemberdayaan pemuda. Melalui skema berbagi/ sharing dan jejaring/networking muncul beragam ide, gagasan dan kebijakan dari banyak pihak, khususnya swasta maupun masyarakat sipil. Hal ini tentu saja menjadi sebuah inovasi kebijakan, tidak hanya bagi pemerintah namun juga bagi aktor-aktor lain yang terlibat serta kaum muda yang menjadi target kebijakan. Keragaman strategi yang muncul menegaskan bahwa semakin banyak pihak yang terlibat maka semakin kaya warna dan karakteristik kebijakan maupun program yang dilakukan.

Berangkat dari kenyataan-kenyataan di atas maka selayaknya perlu ada pembagian peran dan kontribusi dengan para pihak, baik swasta maupun kelompok masyarakat sipil. Strategi ini bukan bermaksud meminggirkan dan menafikan negara namun memperkaya ruang otoritas pemerintah dengan dengan inovasi yang baru, segar, dan telah membawa hasil nyata pada banyak tempat. Oleh karena itu, perlu ada pengkayaan strategi kebijakan yang berkaitan dengan pemberdayaan kaum muda secara inklusif mengingat dari data-data yang ada pemerintah masih belum komprehensif memiliki dan menjalankan kebijakan inklusif. Strategi ini akan membawa banyak manfaat bagi para pihak dan membuktikan bahwa partisipasi dalam politik bersifat nyata dan membawa 
manfaat. Dalam konteks kebijakan dan inovasi maka hal ini justru akan memperkuat peran pemerintah dalam melakukan pemberdayaan bagi kaum muda.

\section{KESIMPULAN}

Pemerintah perlu membuka diri dengan pihak lain untuk mengembangkan strategi dan kebijakan pemberdayaan pemuda sebagai bentuk inovasi dan penguatan strategi kebijakan pemberdayaan. Cerita sukses yang telah terjadi pada belahan bumi lain bisa menjadi bukti dan inspirasi inovasi kebijakan yang dapat dilakukan oleh pemerintah bekerjasama dengan para pihak. Langkah-langkah yang dapat dilakukan oleh pemerintah adalah dengan melakukan peninjauan ulang kebijakan kepemudaan, mengurangi dominasi peran dengan membuka inisiatif forum stakeholder melalui pelibatan sektor privat dan organisasi masyarakat sipil, serta memfasilitasi forum multistakeholder yang terbentuk untuk mengembangkan kebijakan kepemudaan menjadi lebih inklusif. Strategi ini merupakan sebuah inovasi kebijakan sekaligus ajang pelibatan untuk mewujudkan pemerintahan dan kebijakan yang lebih inklusif bagi kaum muda maupun semua warga negara pada umumnya.

\section{DAFTAR PUSTAKA}

Azca, Najib, M. Sutopo, Rahadianto, Oki. Arrobi, Zaki, M. Margono, 2014. "Pendahuluan" Pp. 1-3 dalam Azca, Widhyharto dan Sutopo. Buku Panduan Studi Kepemudaan: Teori, Metodologi, dan Isu-isu Kontemporer. Yogyakarta: Youth Studies Centre UGM.

Balitbang Pemprov Jawa Timur dan Fakultas Ekonomi Universitas Negeri Surabaya. 2014. "Pemberdayaan Karang Taruna dalam Mengembangkan Usaha Ekonomi Produktif untuk Meningkatkan Kesempatan Berusaha dan Lapangan Kerja di Daerah Pedesaan”.

BPS. 2017. "Statistik Pemuda Indonesia”. Diakses pada Maret 2018 (https://www.bps.go.id/).

Bridgman, P. and Davis, G. 2013. The Australian Policy Handbook. Sydney: Allen and Unwin.
Canadian Human Rights Commission. 2006. A Place for All: A Guide to Create an Inclusive Workplace.

Chuncoro, Wahyu, Eko. 2011. "Pemberdayaan Pemuda Pengangguran melalui Pelatihan Kecakapan Hidup (Life Skills) Ternak Kelinci di Desa Botomulyo, Kecamatan Cepiring, Kabupaten Kendal". Skripsi Fakultas Ilmu Pendidikan Universitas Negeri Semarang.

Dudley, G. and Richardson, J. 2000. Why Does Policy Change? : Lessons from B r it is h Transport Policy, 1945-1999. New York: Routledge.

Dye, Thomas R. 2013. Understanding Public Policy. New Jersey: Pearson Education.

Equity and Human Rights Commission. Manchester 2010. An Employer's Guide to Greating An Inclusive Workplace.

Ferretti, Marco. Parmentola, Adele. 2015. The Creation of Local Innovations Systems in Emerging Countries: The Role of Governments, Firms, and Universities. New York: SpringerBriefs in Regional Science.

Grindle, M.S. 2007. Going Local: Decentralization, Democratization, and the Promise of Good Governance. Oxford: Princeton University Press.

Heywood, Andrew. 2013. Politics. Hampsire: Palgrave Macmillan.

Hunmin, Kim. 2006. "Approaches and Means of Innovations in Korean Local Government". The Innovation Journal: The Public Sector Innovation Journal Volume 11 (2).

ILO. 2014. "10 Tahun Menangani Lapangan Kerja bagi Kaum Muda di Indonesia".

ILO. 2015. "Inklusi Penyandang Disabilitas Muda: Kasus Bisnis".

Indrajit, Eko, Richardus. 2006. E-Government in Action: Ragam Kasus Implementasi Sukses di Berbagai Belahan Dunia. Yogyakarta: Andi Publisher. 
Jaser, Abu, Mayyada. Kwauk, Christina. Robinso, Jenny, Perlman. 2015. "Engaging the Privat Sector for Greater Youth Employability in Jordan". Center for Universal Education at Brookings.

Kamarck, Elaine. 2003. Government Innovation Around the World, Ash Institute of Democratic Government and Innovation. Washington DC: Brookings Institution Press.

Kasali, Rhenald. 2015. Change Leadership NonFinito: Masa Depan Ada di Tangan Pemimpin yang Mampu Mengubah Constraint menjadi Kesempatan. Jakarta : Penerbit Mizan.

KEMENPORA. 2017. "Rencana Kerja Kemente rian/Lembaga".

Mark Considine, Jenny M. Lewis, Damon Alexander. 2009. Networks, Innovation and Public Policy: Politicians, Bureaucrats and the Pathways to Change Inside Government. Hampsire: Palgrave Macmillan.

Martell, Christine and Deleon, Peter. 2006. "The Policy Sciences: Past, Present, and Future" Pp. 31-44 dalam Peters and Pierre. Handbook of Public Policy. London: Sage Publications

Martinez, Laia. 2012. "Theoretical Considerations about Innovations in the Public Sector",Sunrise Conference, Roskilde University.
Negara, Siwage, Dharma. 2013. "Membangun Perekonomian Indonesia yang Inklusif dan Berkemajuan". Jurnal Masyarakat Indonesia Vol. 39 No. 1.

Poerwanti, Sari, Dewi. 2017. "Pengelolaan Tenaga Kerja Difable untuk Mewujudkan Work Place Inclusion". INKLUSI Journal of Disability Studies. Vol. 4 No. 1.

Pramusinto, Agus. "Inovasi-inovasi Pelayanan Publik untuk Pengembangan Ekonomi Lokal "Pengalaman Beberapa Daerah". Makalah pada Semiloknas "Perda dalam Pencapaian Tujuan Otonomi Daerah: Peningkatan Akses dan Partisipasi Publik dalam Menelaah Perda untuk Menjamin Transparansi dan Akuntabilitas Pengimplementasian Perda, Jakarta 26-27 Juli 2006.

Victoria State of Govenrment. 2016. Inclusive Organization.

Warsilah, Henny. 2015. "Pembangunan Inklusif Sebagai Upaya Mereduksi Eksklusi Sosial Perkotaan: Kasus Kelompok Marjinal Di Kampung Semanggi, Solo, Jawa Tengah". Jurnal Masyarakat dan Budaya Vol. 17 No. 2.

World Bank. 2013. "Inclusion Matters: The Foundation for Shared Prosperity". 